\title{
AOR
}

Selected Papers of \#AolR2021:

The 22nd Annual Conference of the

Association of Internet Researchers

Virtual Event / 13-16 Oct 2021

\section{SOCIAL MOVEMENTS BUILT ON SOCIAL MEDIA PLATFORMS IN BRAZIL: A STUDY OF HOW TRADITIONAL MEDIA EMBRACED THESE NOVEL FORMS OF CONNECTION AND COMMUNITY}

\author{
Wilson Ceron \\ Federal University of São Paulo, Brazil \\ Mathias-Felipe de-Lima-Santos \\ University of Navarra, Spain
}

The political turmoil unleashed in recent years has influenced how people interact and organize themselves. "Arab Spring" is an example of how communities are a powerful driver of global digital culture. During this social unrest and political upheaval, social media platforms played an important role in the organization of these movements that spilled across the Middle East in early 2011, beginning with Tunisia and continuing across Egypt and into Yemen (Browning, 2013). In this process, many authoritarian governments toppled in the Arab Spring wake. In this respect, some governments like in Egypt attempted to eliminate the nation's Internet access to inhibit the use of social media to generate protests (Overbey et al., 2013).

In another vein, these social movements were underestimated by their importance of self-expression and collective experience. In the case of the Arab Spring protests, it was historically marked by the considerable amount of attention focused on the role of digital technologies in promoting collective activism to circumvent state-operated media channels, that is, the social media platforms served to give voice to these people that were otherwise not represented in the traditional media (Overbey et al., 2013). However, ten years after the uprising, the initial euphoria felt in the Arab world in the immediate aftermath of the uprising proved to be short-lived (Schapals \& Harb, 2021).

In this scenario of political turmoil, Brazil is suffering from an economic downturn and a lack of political leadership in recent years that has resulted in an unprecedented crisis that is causing widespread human suffering, upending lives, devastating forests, threatening democracy, and risking reversals of hard-won progress (Caren et al., 2020; Inclán, 2018). Even before 2016, when the impeachment of the President Dilma Rousseff happened, the turbulent years amid an extensive corruption scandal have heated the people on social media platforms. It was intensified even more after the

Suggested Citation (APA): Ceron, W., \&.de-Lima-Santos, M.F. (2021, October). Social movements organized built on social media platforms in Brazil: A study of how traditional media embraced these novel forms of connection and community. Paper presented at AolR 2021: The 22nd Annual Conference of the Association of Internet Researchers. Virtual Event: AolR. Retrieved from http://spir.aoir.org. 
victory of Jair Bolsonaro and the "right turn" of Brazilian politics. In this almost decade of crises (political, economic, and social), social movements have taken to social media to organize protests (Caren et al., 2020).

In our study, we consider the 2013 protests in Brazil, also known as "June Journeys" (Jornadas de Junho, in Portuguese) as the initial point of articulation on social media platforms that galvanized movements to pressure the Brazilian government to develop and implement policies to mitigate corruption and its consequences and ensure a more sustainable pathway for the population. Although it started against increases in public transportation fare prices, this movement grew to include other issues such as the police brutality used against demonstrators. Similar to Arab Spring, social media has played a fundamental and influential role in the organization of public outcries and in keeping protesters in touch among them. Hence, this movement was considered "Brazilian Spring" (Caren et al., 2020; Inclán, 2018).

Since then, another social movement has attracted attention not only from the government but also from the media. The 2018 Brazil truck drivers' strike, also called the diesel crisis, drew significant attention, as the paralysis of roads caused a shortage of food, medicines, and oil across the country. Disparate bands of truckers turned to WhatsApp and Facebook to unite thousands of drivers in the largest truckers strike in the nation's history (Lopes, 2018). With the same emphasis on movement building and coalition work on online social media, the panelaço gained popularity after the protests against the former president Dilma Rousseff in 2015 (Magalhães, 2020). Inspired by the Italian cacerolazo, it became a form of popular protest in Brazil, in which people make noise by banging pots, pans, and other utensils to call for attention. These demonstrations are organized using these platforms to have a coordinated action.

Considering that all these three movements were built in the new media, traditional news media has been impacted by these events. Influenced by these social dynamics of the platforms, these movements represent an evolving power trend in society. Since social movements attempt to replace "a dominant belief system that legitimizes the status quo with an alternative mobilizing belief system that supports collective action for change" (Gamson et al., 1982, p. 15), Brazilian news media have to report on these events under a myriad of contextual control, in some cases diminishing their strength, in others multiplying it (Harlow, 2012; Harlow et al., 2020). Although there are many studies, the research in Brazil remains limited. Therefore, this study aimed to answer the following research questions:

RQ1: How does traditional media frame these movements?

RQ2: How are these movements interconnected according to the media?

To fill this gap in the literature, this study, under the lens of sociology and social media theory, examines the evolution of these movements using data gathered from GNews API (Barua et al., 2019; Gupta et al., 2021; Hswen et al., 2020). Data was composed of news articles published from January 2013, the time that the first event occurred, until January 2021, when the COVID-19 death reached a boom in the city of Manaus in the north of Brazil, leading to a great panelaço (Marreiro, 2021). In order to understand how the media frames these social movements and provide a contextual context of how 
these movements are interrelated (Goffman, 1974), we conducted a time-series analysis to identify the peaks of these events. Based on these initial results, we randomly selected 40 news stories from legacy news media when peaks occur to analyze how the media framed these events, according to code frames derived from an initial exploratory analysis of a sample, then defined in a codebook (Matthes, 2009).

Our initial findings indicate that there is a strong critique about some of these movements as they are challenging pre-existing power relationships that the traditional news media had. Additionally, news media use these movements to report on governmental actions and dilemmas, and, at the same time, to remain in the illusionary 'objectivity' (Tong \& Zuo, 2019). Although these groups brought some level of independence from the media and influence on salient issues covered by the media (Lippmann, 1921; Walgrave \& Van Aelst, 2006), the promises to break from the constraints of traditional media and embrace novel forms of connection and community are yet limited. We can argue that these three movements are at some level interconnected, due to the strong influence of the political destabilization in Brazil. On the other hand, echoing the findings in the Arab Spring movement (Schapals \& Harb, 2021), the initial euphoria of these movements proved to be short-lived.

\section{References}

Barua, R., Maity, R., Minj, D., Barua, T., \& Layek, A. K. (2019). F-NAD: An Application for Fake News Article Detection using Machine Learning Techniques. 2019 IEEE Bombay Section Signature Conference, IBSSC 2019, 2019Januar, 1-6. https://doi.org/10.1109/IBSSC47189.2019.8973059

Browning, J. G. (2013). Democracy Unplugged: Social Media, Regime Change, and Governmental Response in the Arab Spring. Michigan State International Law Review, 21(1), 63-86.

http://search.ebscohost.com/login.aspx?direct=true \&db=Igs\&AN=88845251\&site=e host-live

Caren, N., Andrews, K. T., \& Lu, T. (2020). Contemporary social movements in a hybrid media environment. Annual Review of Sociology, 46, 443-465. https://doi.org/10.1146/annurev-soc-121919-054627

Gamson, W. A., Fireman, B., \& Rytina, S. (1982). Encounters with unjust authority. Dorsey Press.

Goffman, E. (1974). Frame Analysis: An Essay on the Organization of Experience. In American Journal of Psychiatry (Vol. 132, Issue 10). Harper \& Row. https://doi.org/10.1176/ajp.132.10.1093-a

Gupta, V., Beckh, K., Giesselbach, S., Wegener, D., \& Wirtz, T. (2021). Supporting verification of news articles with automated search for semantically similar articles. CEUR Workshop Proceedings, 2838, 47-58. http://arxiv.org/abs/2103.15581 
Harlow, S. (2012). Social media and social movements: Facebook and an online Guatemalan justice movement that moved offline. New Media and Society, 14(2), 225-243. https://doi.org/10.1177/1461444811410408

Harlow, S., Kilgo, D. K., Salaverría, R., \& García-Perdomo, V. (2020). Is the Whole World Watching? Building a Typology of Protest Coverage on Social Media From Around the World. Journalism Studies, 21(11), 1590-1608.

https://doi.org/10.1080/1461670X.2020.1776144

Hswen, Y., Zhang, A., Freifeld, C., \& Brownstein, J. S. (2020). Evaluation of volume of news reporting and opioid-related deaths in the United States: Comparative analysis study of geographic and socioeconomic differences. Journal of Medical Internet Research, 22(7), e17693. https://doi.org/10.2196/17693

Inclán, M. (2018). Latin America, a continent in movement but where to? A review of social movements' studies in the region. Annual Review of Sociology, 44, 535-551. https://doi.org/10.1146/annurev-soc-073117-041043

Lippmann, W. (1921). Public Opinion.

Lopes, M. (2018, June 11). WhatsApp is upending the role of unions in Brazil. Next, it may transform politics. The Washington Post.

https://www.washingtonpost.com/world/the_americas/whatsapp-is-upending-therole-of-unions-in-brazil-next-it-may-transform-politics/2018/06/09/777e537e-68cc11e8-a335-c4503d041eaf_story.html

Magalhães, G. (2020, March 18). Símbolo latino-americano, panelaço marcou Dilma e foi usado de esquerda à direita. Folha de S. Paulo.

https://www1.folha.uol.com.br/poder/2020/03/simbolo-latino-americano-panelacomarcou-dilma-e-foi-usado-de-esquerda-a-direita.shtml

Marreiro, F. (2021, January 15). Crise de Manaus comove Brasil e panelaço ressurge forte contra Bolsonaro. EL PAÍS Brasil. https://brasil.elpais.com/brasil/2021-0115/crise-de-manaus-comove-brasil-e-panelaco-ressurge-forte-contrabolsonaro.html

Matthes, J. (2009). What's in a frame? A content analysis of media framing studies in the world's leading communication journals, 1990-2005. Journalism and Mass Communication Quarterly, 86(2), 349-367. https://doi.org/10.1177/107769900908600206

Overbey, L. A., Greco, B., Paribello, C., \& Jackson, T. (2013). Structure and prominence in Twitter networks centered on contentious politics. Social Network Analysis and Mining, 3(4), 1351-1378. https://doi.org/10.1007/s13278-013-0134-8

Schapals, A. K., \& Harb, Z. (2021). "Everything Has Changed, and Nothing Has Changed in Journalism": Revisiting Journalistic Sourcing Practices and Verification Techniques during the 2011 Egyptian Revolution and Beyond. Digital Journalism, O(0), 1-20. https://doi.org/10.1080/21670811.2020.1856702 
Tong, J., \& Zuo, L. (2019). The Inapplicability of Objectivity: Understanding the Work of Data Journalism. Journalism Practice, 1-17.

https://doi.org/10.1080/17512786.2019.1698974

Walgrave, S., \& Van Aelst, P. (2006). The contingency of the mass media's political agenda setting power: Toward a preliminary theory. Journal of Communication, 56(1), 88-109. https://doi.org/10.1111/j.1460-2466.2006.00005.x 